慶應義塾大学学術情報リポジトリ

Keio Associated Repository of Academic resouces

\begin{tabular}{|c|l|}
\hline Title & EFFECT OF NUMBER OF FASCICLE ON AXONAL REGENERATION IN CABLE GRAFTS \\
\hline Sub Title & Cable GraRにおける移植神経片数が軸索再生に及ぼす影響 \\
\hline Author & 奥山, 訓子(Okuyama, Noriko) \\
\hline Publisher & 慶應医学会 \\
\hline Publication year & 2005 \\
\hline Jtitle & 慶應医学 (Journal of the Keio Medical Society). Vol.82, No.2 (2005. 6),p.27- \\
\hline JaLC DOI & \\
\hline Abstract & \\
\hline Notes & 号外 \\
\hline Genre & Journal Article \\
\hline URL & $\begin{array}{l}\text { https://koara.lib.keio.ac.jp/xoonips/modules/xoonips/detail.php?koara_id=AN00069296-2005060 } \\
\text { 2-0027 }\end{array}$ \\
\hline
\end{tabular}

慶應義塾大学学術情報リポジトリ(KOARA)に掲載されているコンテンツの著作権は、それぞれの著作者、学会または出版社/発行者に帰属し、その権利は著作権法によって 保護されています。引用にあたっては、著作権法を遵守してご利用ください。

The copyrights of content available on the KeiO Associated Repository of Academic resources (KOARA) belong to the respective authors, academic societies, or publishers/issuers, and these rights are protected by the Japanese Copyright Act. When quoting the content, please follow the Japanese copyright act. 


\title{
EFFECT OF NUMBER OF FASCICLE ON AXONAL REGENERATION IN CABLE GRAFTS
}

\author{
（Cable Graftにおける移植神経片数が軸索再生に及ぼす影響）
}

\section{奥 山 訓 子}

\section{内容の要旨}

【目的】臨床における末梢神経欠損の再建では、ホスト神経とほぼ同 径のcable graftを作成して移植することが多い。しかし移植神経片を 利用した神経再生の様式は実験的に明らかにされておらず、再生神経 の誘導に必要十分な移植神経片の太さについては、いまだ十分な検討 がなされていない。本研究の目的は、動物モデルを用いて断面積の異 なるcable graftの神経誘導能を比較検討することである。

【材料・方法】Wistarラットの切断した後脛骨神経に、20mmの腓腹神 経を移植した（実験モデルA）。移植神経片の数により、5本群、3 本群（ホスト神経とほぼ同径）、1 本群の3 群を設定した。移植後 16 週で、移植神経より末梢、移植部中央、近位の 3 か所で横断切片を作 成し、光学顕微鏡を用いて軸索数と軸索密度、断面積を計測し組織形 態学的評価を行った。経時的歩行解析による機能回復度評価も行っ た。また、シリコンチューブで移植神経片全長を被覆したモデルB、 シリコンチューブを介し接合したモデルCを作成して同様に 3 群に ついて検討し、接合部における縫合操作の軸索再生への影響を評価し た。

【結果】全個体で移植部・末梢ともに大径の再生有㕼軸索がみられた。 移植神経片の間隙にも有䯣軸索が観察された。モデルB、Cでの 3 群間 の軸索数、密度に有意差はなく、檤合操作の影響はないと考えた。実 験モデルAにおける移植部での軸索数 (平均士SD本) は、5 本群、3 本群、1本群でそれぞれ10795 $44430 、 8953 \pm 4428 、 5089 \pm 2212$ であり、 3 本群、5 本群で有意に多くの軸索が観察された。末梢部では4226士

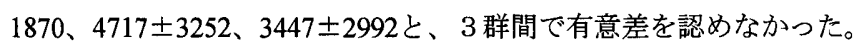
軸索密度では、移植部、末梢部ともに 3 群間に有意差を認めなかった。 移植部での移植神経片断面積 $\left(\mathrm{mm}^{2}\right)$ は 5 本群、3 本群、1 本群でそ れぞれ、0.23 $\pm 0.16 、 0.13 \pm 0.04 、 0.07 \pm 0.03$ と、 3 本群、 5 本群が有意 に大きかった。機能回復度も全経過を通じて 3 群間に有意差はなかっ た。

【考察】本研究で、小さい断面積の 1 本群が $3 、 5$ 本群に抙色ない軸 索再生能を有することが明らかとなった。これは移植神経片間隙に観 察された再生軸索が末梢のホスト神経に誘導され有効に利用された ことによると考えた。また、採取時の断面積比が移植時の $1: 3: 5$ に対し1：2：3 となったことから、小さい径のcable graftでは移植 神経片が径を大きくして、より多くの再生軸索を受け入れたことも関 与していると考えた。

【結語】ホストより断面積の小さいcable graftが、同径以上のものに匹 敵する機能的軸索再生を誘導できることが明らかとなった。

\section{論文審査の要旨}

臨床における末梢神経欠損の再建では、一般にホスト神経とほぼ同 径の神経束移植 (cable graft) が行われているが、移植神経片を利用し て軸索が再生する機序は明らかではない。本研究では、動物モデルを 用いて断面積の異なる cable graftの神経誘導能を比較検討した。Wistar ラットの切断した後脛骨神経に腓腹神経を移植し、移植神経片の数に より 5 本群、3 本群 (ホストとほぼ同径)、1 本群の 3 群を設定した。 移植後 16 週で、移植神経より遠位、移植部中央、近位の 3 か所で横断 切片を作製し、光学顕微鏡を用いて軸索数と軸索密度、断面積を計測 し組織形態学的評価を行った。経時的歩行解析による機能回復度評価 も行った。また、シリコンチューブを介して接合したモデルを用いて 接合部における縫合操作の軸索再生一の影響を除外できることを確 認した。移植部、未梢部ともに大径の再生有髄軸索が観察され、移植 神経片の間隙にも有髄軸索が観察された。移植部での軸索数は 3 本 群、 5 本群で有意に多く、末梢部では 3 群間で有意差を認めなかった。 軸索密度には移植部、末梢部ともに 3 群間に有意差を認めなかった。 移植部での移植神経片断面積は 3 本群、5 本群が有意に大きかった が、断面積比は 1 本群: 3 本群 : 5 本群で $1: 2: 3$ と不均等な拡大 傾向を示した。全経過を通じ機能回復度に 3 群間の有意差はなかっ た。小さい断面積の 1 本群が $3 、 5$ 本群に遜色ない軸索再生を誘導し 得たのは、移植神経片間隙に観察された再生軸索が末梢のホスト神経 に誘導され有効に利用されたこと、小さい径のcable graftで移植神経 片が径を大きくしてより多くの再生軸索を受け入れたことが関与し ていると考えた。以上より、ホストより断面積の小さいcable graftが、 同径以上のものに匹敵する機能的軸索再生を誘導できることが示唆 された。

審查では、まず間隙に再生した軸索と移植神経片内の軸索の質的な 差異につき質問された。それに対して末梢に誘導された軸索は均一で あり両者に差異はないと考えていると回答がなされた。また、軸索の 径を増やす成分について質問がなされ、主な成分は軸索であるとの回 答がなされた。さらに移植神経片間隙の基質成分について質問がなさ れ、今後の確認を要すると示唆を受けた。また、逆行性のラベリング やGFP発現ラットを用いて再生軸索の由来を明らかにすべく更なる 検証を要すること、伝導速度など電気生理学的検証の裹づけを行うこ と、実験個体数を増やし統計学的有意差に確実性をもたせることな ど、今後の課題について示唆を受けた。

以上のように、本研究はさらに検討されるべき点をのこしている ものの、細いcable graftが同じ径以上のcableに匹敵する軸索再生を誘 導する可能性を示し、今後臨床応用が期待されるという点で有意義 であると評価された。

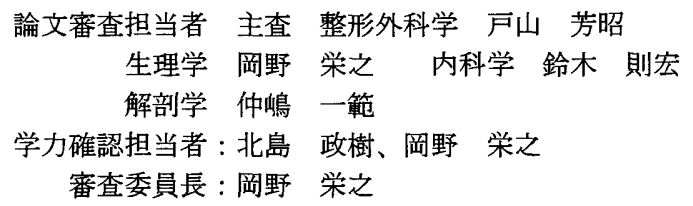

試問日：平成17年 2月 9日 